\title{
Does one model fit all? Patterns of beech mortality in natural forests of three European regions
}

\author{
Lisa Hülsmann, $1,2,5$ Harald K. M. Bugmann, ${ }^{2}$ Brigitte Commarmot, ${ }^{1}$ Peter Meyer, ${ }^{3}$ \\ Stephan Zimmermann, ${ }^{4}$ And Peter Brang ${ }^{1}$ \\ ${ }^{1}$ Research Unit Forest Resources and Management, WSL Swiss Federal Institute for Forest, Snow and Landscape Research, \\ Zürcherstrasse 111, 8903 Birmensdorf, Switzerland \\ ${ }^{2}$ Forest Ecology, Institute of Terrestrial Ecosystems, ETH Zurich, Universitätstrasse 16, 8092 Zürich, Switzerland \\ ${ }_{3}^{3}$ Sachgebiet Waldnaturschutz/Naturwald, Nordwestdeutsche Forstliche Versuchsanstalt NW-FVA, Grätzelstrasse 2, 37079 \\ Göttingen, Germany \\ ${ }^{4}$ Research Unit Forest Soils and Biogeochemistry, WSL Swiss Federal Institute for Forest, Snow and Landscape Research, \\ Zürcherstrasse 111, 8903 Birmensdorf, Switzerland
}

\begin{abstract}
Large uncertainties characterize forest development under global climate change. Although recent studies have found widespread increased tree mortality, the patterns and processes associated with tree death remain poorly understood, thus restricting accurate mortality predictions. Yet, projections of future forest dynamics depend critically on robust mortality models, preferably based on empirical data rather than theoretical, not well-constrained assumptions. We developed parsimonious mortality models for individual beech (Fagus sylvatica L.) trees and evaluated their potential for incorporation in dynamic vegetation models (DVMs). We used inventory data from nearly 19,000 trees from unmanaged forests in Switzerland, Germany, and Ukraine, representing the largest dataset used to date for calibrating such models. Tree death was modelled as a function of size and growth, i.e., stem diameter $(d b h)$ and relative basal area increment (relBAI), using generalized logistic regression accounting for unequal re-measurement intervals. To explain the spatial and temporal variability in mortality patterns, we considered a large set of environmental and stand characteristics. Validation with independent datasets was performed to assess model generality. Our results demonstrate strong variability in beech mortality that was independent of environmental or stand characteristics. Mortality patterns in Swiss and German strict forest reserves were dominated by competition processes as indicated by J-shaped mortality over tree size and growth. The Ukrainian primeval beech forest was additionally characterized by windthrow and a U-shaped size-mortality function. Unlike the mortality model based on Ukrainian data, the Swiss and German models achieved good discrimination and acceptable transferability when validated against each other. We thus recommend these two models to be incorporated and examined in DVMs. Their mortality predictions respond to climate change via tree growth, which is sufficient to capture the adverse effects of water availability and competition on the mortality probability of beech under current conditions.
\end{abstract}

Key words: climate change; dynamic vegetation models; external validation; Fagus sylvatica; forest inventory data; forest reserves; generalized logistic regression; individual tree mortality.

\section{INTRODUCTION}

Increasing tree mortality in response to global climate change is receiving particular attention (Allen et al. 2010, Steinkamp et al. 2015). However, tree mortality and particularly its spatial patterns and temporal variability remain poorly understood (Hawkes 2000), partly due to its "stochastic, rare and irregular" nature (Eid and Tuhus 2001). Consequently, the future development of forests, which depends critically on tree mortality (Friend et al. 2014), is highly uncertain. Robust, widely applicable models of individual tree mortality are sorely needed as they allow for insights into mortality patterns and at the same time for projections of future tree mortality.

Manuscript received 21 March 2016; revised 13 May 2016; accepted 24 May 2016. Corresponding Editor: E. Cienciala.

5E-mail: lisa.huelsmann@wsl.ch
Although several attempts toward model improvement have been made, robust, climate-sensitive tree mortality models continue to be lacking (Weiskittel et al. 2011, Bircher et al. 2015). In particular, dynamic vegetation models (DVMs) at stand, landscape, and global scales, which are a key tool to quantify future changes of forest ecosystems, typically include theoretical mortality algorithms that lack mechanistic and/or empirical justification. This strongly hampers the reliability of DVM projections (Keane et al. 2001, Reyer et al. 2015).

Fully mechanistic tree mortality models still have a long way to go due to insufficient understanding of the underlying physiological processes (Wang et al. 2012). Therefore, a promising approach for progress in mortality models appears to be empirical, i.e., using different kinds of datasets to elucidate the relationship between the likelihood of tree death and variables that are internal or 
external to the tree (Weiskittel et al. 2011). To date, three distinct strategies have been pursued to this end: (1) using tree size, vitality, and competition within the stand (e.g., Monserud and Sterba 1999), (2) using tree size and tree growth (e.g., Holzwarth et al. 2013), and (3) using tree age in combination with environmental variables (e.g., Neuner et al. 2015).

In all three approaches, tree age or attributes characterizing tree size, such as diameter at breast height $(d b h)$, account for the increased mortality risk of young or small trees that are often suppressed. The U-shaped relationship between $d b h$ and mortality probability that has sometimes been found accounts for higher mortality of large trees as a consequence of mechanical instability and higher susceptibility to disturbance and, finally, senescence (Harcombe 1987). Growth rates are used as a predictor of mortality probability to capture that trees exposed to stress allocate, in comparison to vigorous individuals, fewer resources to radial stem growth, which has low priority compared to photosynthetic tissue and root growth over short time scales (Waring 1987).

In the absence of larger disturbances, tree mortality rates are typically low, i.e., $0.5-3 \%$ per yr (Peterken 1996), and therefore datasets for deriving the relationship between tree size, growth, and regular, i.e., noncatastrophic mortality considering species and site differences, must be large (Metcalf et al. 2009, Lutz 2015). Such datasets are available from long-term remeasurements of permanent plots (e.g., Wunder et al. 2008) or from increment cores (e.g., Bigler and Bugmann 2003). Although inventory data have a lower temporal resolution than dendrochronological data, they allow for the estimation of both individual mortality probabilities and population-based mortality rates (Weiskittel et al. 2011). Several models focusing mainly on regular tree mortality were developed for European beech (Fagus sylvatica L.), one of the most widespread species of Central Europe. Most of them are based on inventory datasets, e.g., from Switzerland (Dobbertin and Brang 2001, Wunder et al. 2007, 2008), Germany (Dursky 1997, Ahner and Schmidt 2011, Holzwarth et al. 2013, Nothdurft 2013, Boeck et al. 2014, Neuner et al. 2015), or Austria (Hasenauer 1994, Monserud and Sterba 1999). Mortality models for beech based on dendrochronological data were developed by Gillner et al. (2013) for eastern Germany. Most of the datasets used in these efforts were relatively lean due to sparse geographical coverage and a small sample size in terms of total tree number and particularly the number of dead trees (Wyckoff and Clark 2002). Large inventory datasets from strict forest reserves are of particular value for the calibration of mortality models as forest management was given up several to many decades ago, such that natural mortality is higher than in managed forests (Bravo-Oviedo et al. 2006).

Tree mortality is characterized by high temporal and spatial variability due to complex interactions of multiple factors (Franklin et al. 1987). This variability remains poorly understood (Wunder et al. 2008, Dietze and Moorcroft 2011) and thus complicates the derivation of generally applicable mortality models (Hawkes 2000). We identify three areas where important knowledge gaps should be filled.

First, although mortality models based on tree size and growth alone have achieved good performance at the site to regional levels and thus appear promising for application, e.g., in forest gap models (Bircher et al. 2015), the potential of additional environmental or stand characteristics (e.g., water availability, competition) for explaining the temporal and spatial variability of mortality over larger areas has not been studied in detail. Specifically, it remains unclear whether growth sufficiently integrates the effects of climate, soil, and stand structure on mortality, or whether such covariates could increase the performance of growth-based tree mortality models. In particular, drought has been identified as an important driver of growth decline and tree mortality of European beech (Jung 2009, Lakatos and Molnár 2009, Scharnweber et al. 2011, Zimmermann et al. 2015), and its impacts are hotly debated in the context of climate change (Geßler et al. 2007).

Second, the processes relevant for a tree's death vary during its lifetime (Holzwarth et al. 2013), and thus the reliability of mortality predictions given a particular model structure may vary with tree size. Although the relative importance of the formulations contained in DVMs against the backdrop of uncertainties in the data, model parameters, and process representations (Lek 2007) is more and more investigated using sensitivity analysis (Wernsdörfer et al. 2008), the impact of tree size on model accuracy has not been evaluated to date.

Third, the application of empirical mortality models in DVMs must inevitably be based on the assumption of a stable relationship between the explanatory variables and mortality (Keane et al. 2001). However, current empirical mortality models are strongly restricted by their calibration domain in terms of space, time, and resolution, referred to as the "scope of inference" (Woolley et al. 2012) or "temporal and spatial inflexibility" (Hawkes 2000). Therefore, a rigorous external validation of the mortality functions is required to assess their applicability beyond the conditions for which they have been calibrated. Since to date, all beech mortality models except for the one developed by Dobbertin and Brang (2001) are lacking an external validation with independent data, it is simply unknown whether such empirical models are appropriate for the application across larger areas or over longer time spans.

Therefore, the main objective of this study was to develop parsimonious models for regular beech mortality based on extensive inventory data from strict forest reserves and to comprehensively evaluate their performance. Specifically, we aimed to answer three questions: (1) Does the growth-mortality relationship vary with site and stand characteristics, and particularly with water availability and competition? (2) How strongly does the 
prediction and classification accuracy of mortality models vary with tree size and between different sites? (3) How well do mortality models perform when applied outside their calibration range, i.e., in other forest reserves and in a primeval beech forest?

\section{Materials And Methods}

\section{Study areas and sites}

Datasets from inventories with similar design in strict forest reserves in Switzerland and Germany (Lower Saxony) were used (Appendix S1: Figure S1; cf. Meyer et al. 2006, Brang et al. 2011). Every reserve included up to 10 permanent plots ranging from 0.09 to 1.8 ha in size, with slightly irregular re-measurement intervals (Table 1). Permanent plots with pure or mixed beech stands were selected from the reserves of both networks. Reserves with considerable wind disturbance during the monitored intervals were excluded from the analysis. The Swiss and German reserves had been established in the periods of 1961-1975 and 1971-1974, respectively. Former management ranged from no or only weak thinning to regular thinning from above and coppice with standards in Switzerland (Heiri et al. 2009) and thinning from below in Germany. In addition to data from the Swiss and German reserves, data from a 10-ha plot in the primeval beech forest Uholka in Western Ukraine were used (Table 1; cf. Commarmot et al. 2005).

Climatic conditions of the Swiss and German reserves are similar in terms of mean annual air temperature (Switzerland, 5.4-9.1 ${ }^{\circ} \mathrm{C}$, Germany, $6.1-9.0^{\circ} \mathrm{C}$ for 1961-1990; cf. DAYMET model in Appendix S2 and Gauer and Aldinger 2005), but mean annual precipitation sums of the German reserves are lower (Switzerland, 922-1,842 mm, Germany, 618-1,312 mm), whereas the Ukrainian forest has intermediate climatic conditions $\left(7.7^{\circ} \mathrm{C}\right.$ for $1990-2010,1,134 \mathrm{~mm}$ for 1980 2010; Commarmot et al. 2013). Stand characteristics of the reserves indicate moderate structural differences with higher basal area (BA) but lower mean $d b h$ in the
Swiss reserves compared to the German and Ukrainian forests (Appendix S1: Table S1). Accordingly, also the stand density index (SDI) calculated following Reineke (1933) was larger in Swiss reserves. The German forests are mixed with spruce (Picea abies Karst, 8.4\% of BA on average) and oak (Quercus petraea Liebl. and Q. robur L., 5.1\%) and have a larger proportion of beech $(78.6 \%)$ than the Swiss stands $(43 \%)$, which feature considerable shares of oak $(16.3 \%)$, spruce (7.5\%), ash (Fraxinus excelsior L., 7.3\%), and fir (Abies alba Mill., 7.2\%). The Ukrainian forest is an almost pure beech stand. Ten-year tree mortality rates were highly variable between reserves, ranging from $2.7 \%$ to $21.5 \%$ (calculated for trees with a $d b h>8 \mathrm{~cm}$ ). Mortality rates in the German reserves were approximately half the mortality rates in the Swiss and Ukrainian stands (Appendix S1: Table S1).

\section{Mortality information and tree characteristics}

A set of three consecutive inventories was used to generate records for the calibration of mortality models based on trees that were alive in the first and second inventory and either dead or alive in the third inventory. Since for a considerable proportion of the Swiss and German permanent plots (54.3\% and 33.3\%, respectively) more than three inventories were available, individual trees can appear more than once in the dataset as all possible sets of inventory data were used for model development (Table $1 ; 32.1 \%$ of the records are such repeated measures). Multiple records per tree were treated as independent (cf. Appendix S1: Figure S2 for further details). The inventory data provide diameter measurements at breast height $(d b h)$ for revisited trees with $d b h \geq 4,7$, and $6 \mathrm{~cm}$ for Switzerland, Germany, and Ukraine, respectively.

As an explanatory variable, the annual relative basal area increment (relBAI, cf. Bigler and Bugmann 2004) was calculated based on the first and the second $d b h$ measurement as the compound annual growth rate of the trees basal area $\mathrm{BA}_{i}$ using

TABLE 1. Extent of the inventory data from Swiss, German, and Ukrainian strict forest reserves.

\begin{tabular}{lcccccccc}
\hline \hline $\begin{array}{l}\text { Reserve } \\
\text { (network) }\end{array}$ & $\begin{array}{c}\text { Interval } \\
\text { length } \\
\text { (yr) }\end{array}$ & $\begin{array}{c}\text { Number } \\
\text { of reserves }\end{array}$ & $\begin{array}{c}\text { Number } \\
\text { of plots }\end{array}$ & $\begin{array}{c}\text { Number } \\
\text { of trees }\end{array}$ & $\begin{array}{c}\text { Number } \\
\text { of records }\end{array}$ & $\begin{array}{c}\text { Number } \\
\text { of dead } \\
\text { trees }\end{array}$ & $\begin{array}{c}\text { Size of } \\
\text { permanent } \\
\text { plots (ha) }\end{array}$ & Application \\
\hline $\begin{array}{c}\text { Switzerland } \\
\text { (reduced) }\end{array}$ & $5-18$ & 13 & 43 & 7,640 & 12,822 & 2,414 & $0.09-1.32$ & $\begin{array}{c}\text { environmental and stand } \\
\text { influences } \\
\text { calibration/validation } \\
\text { calibration/validation }\end{array}$ \\
$\begin{array}{l}\text { Switzerland } \\
\begin{array}{c}\text { Germany } \\
\text { (Lower }\end{array}\end{array}$ & $5-18$ & 15 & 81 & 12,114 & 18,369 & 3,194 & $0.09-1.32$ \\
$\begin{array}{c}\text { Saxony) } \\
\text { Ukraine } \\
\text { (Uholka) }\end{array}$ & 5 & 13 & 21 & 4,377 & 5,938 & 503 & $0.48-1.80$ & \\
\hline
\end{tabular}

Notes: The reduced Swiss dataset with available soil profile data was used to assess the influence of additional environmental and stand characteristics on beech mortality. Since for a considerable proportion of the Swiss and German permanent plots (54.3\% and $33.3 \%$, respectively) more than three inventories were available, individual trees can appear more than once in the dataset (compare number of trees and records). $32.1 \%$ of the Swiss and German records are such repeated measures. 


$$
\operatorname{relBaI}_{i}=\left(\frac{\mathrm{BA}_{i, 2 \mathrm{nd}}}{\mathrm{BA}_{i, 1 \mathrm{st}}}\right)^{1 / \Delta t}-1
$$

with $\Delta t$ denoting the number of years of the growth period.

Tree $d b h$ in the second inventory was used in addition to relBAI to model tree status (alive or dead) of the third inventory. First-aid transformations were applied as suggested for only-positive data (Mosteller and Tukey 1977) to improve the relationship of the explanatory variables and mortality. Thus, $d b h$ was log-transformed. relBAI was transformed using a modified log-transformation (logst) to achieve finite values even for those $11 \%$ of the trees for which no growth $(r e l B A I \leq 0)$ was observed (Stahel 2008). The respective transformation threshold $c$ was calibrated to the combined relBAI values of Switzerland, Germany, and Ukraine.

\section{Environmental and stand characteristics}

To increase the generality of the mortality models, we selected environmental variables that are known to have a considerable influence on growth and mortality of beech because they challenge the plant's physiological system, e.g., frost (cf. Charrier et al. 2013) and drought (increased transpiration, reduced photosynthesis along with excessive respiration; cf. McDowell et al. 2013), or because they influence resource availability, e.g., soil properties and competition. We emphasized the effects of water availability using a large set of drought characteristics that were calculated based on the local site water balance. Following Nothdurft (2013) and Neuner et al. (2015), we also related beech mortality to temperature and precipitation. The time available for annual tree growth was considered using growing degree-days. Nutrient supply, which influences tree growth but is less critical for survival, was considered by using the proxy variable soil $\mathrm{pH}$. The database and derivation of the environmental variables are described in detail in Appendix S2. Climate and drought variables were calculated for the entire year and/or for the growing season, i.e., from April to September ( $G$; Table 2$)$. Temperature was additionally averaged for the months January to March $(W)$. Since drought and other climatic drivers may have a delayed effect on mortality (Berdanier and Clark 2016), all variables were calculated for the growth period (i.e., between the first and the second inventory) and the mortality period (i.e., between the second and third inventory period).

Since not only climate and soil may affect growth and mortality, we additionally considered stand characteristics that reflect the development stage, competition, and structure of the forests (Gendreau-Berthiaume et al. 2016). As a proxy for stand age and structural complexity, the mean, median, and interquartile range (IQR) of $d b h$ were calculated. To capture stand density, BA and the number of trees per ha $(N)$ were derived. Stand characteristics were calculated for the second inventory of each record based on all living trees. We did not include variables based on maximum size-density concepts (e.g., Yoda et al. 1963) since their application to complex, uneven-aged, and mostly multi-species stands such as those in our study is not appropriate.

Overall, 31 environmental and stand characteristics were used to examine the influence of climate, site factors, and stand properties on the relationship of $d b h$ and relBAI to beech mortality probability. Due to data availability, these in-depth analyses could be performed for a subset of the Swiss sites only (cf. Appendix S2; Table 2).

\section{Mortality model}

Mortality probability $p$ was modeled using logistic regression (Weiskittel et al. 2011) where $p$ is related to the inverse logit transformation of the linear predictor

$$
p_{i, \Delta t=1}=\operatorname{logit}^{-1}\left(X_{i} \beta\right)=\frac{\exp \left(X_{i} \beta\right)}{1+\exp \left(X_{i} \beta\right)}
$$

with $p_{i, \Delta t}=1$ denoting the annual mortality probability of tree $i, X_{i}$ the design matrix of the linear predictor and $\beta$ the respective parameter vector. Since the length of the mortality period was not constant for all observations in the inventory datasets, $p_{i, \Delta t}=1$ was scaled to the length of the respective mortality period of $\Delta t$ years following Monserud (1976) using

$$
p_{i, \Delta t}=1-\left(1-p_{i, \Delta t=1}\right)^{\Delta t}
$$

resulting in a generalized logistic regression approach (Yang and Huang 2013). The scaled mortality probability $p_{i, \Delta t}$ was used as a predictor for tree status $y_{i}$ ( $1=$ dead, $0=$ alive $)$, which was assumed to be binomially distributed. To estimate the parameters of $\beta$, the loglikelihood $L L$ matching $p_{i, \Delta t}$ and $y_{i}$ after $\Delta t$ years was maximized:

$$
\operatorname{LL}(\beta)=\sum_{i=1}^{n}\left\{y_{i} \times \ln \left(p_{i, \Delta t}\right)+\left(1-y_{i}\right) \times \ln \left(1-p_{i, \Delta t}\right)\right\} .
$$

Standard errors, confidence intervals, and $p$ values were calculated based on the Fisher information taken from the Hessian matrix.

\section{Performance criteria}

The performance of the models was assessed as good calibration (i.e., correct mortality rates) and good discrimination (i.e., correct attribution of dead/alive status). During model selection, the Brier Score $(B S)$ defined as

$$
B S=\frac{1}{n} \sum_{i=1}^{n}\left(p_{i, \Delta t}-y_{i}\right)^{2}
$$

was applied, indicating good calibration and discrimination when being small (Steyerberg et al. 2010).

Since calibration and discrimination skills of a model are not necessarily correlated (Bravo-Oviedo et al. 2006), the prediction bias $\left(p_{\text {bias }}\right)$ and the area under the receiver 
TABLE 2. Environmental and stand characteristics considered within the beech mortality model for the reduced Swiss dataset.

\begin{tabular}{|c|c|c|c|c|c|c|c|}
\hline Covariates & Abbreviation & Type & $\begin{array}{l}\text { Seasonal } \\
\text { level }\end{array}$ & $\begin{array}{l}\text { Period or } \\
\text { inventory }\end{array}$ & Transformation & Range & Unit \\
\hline $\begin{array}{l}\text { Mean diameter at } \\
\text { breast height }\end{array}$ & dbh.mean. 2 & stand & $\ldots$ & second & sqrt & $100-373$ & $\mathrm{~mm}$ \\
\hline $\begin{array}{l}\text { Interquartile range of } \\
\text { diameter at breast } \\
\text { height }\end{array}$ & $d b h . \mathrm{IQR} .2$ & stand & $\ldots$ & second & sqrt & $41-324$ & $\mathrm{~mm}$ \\
\hline $\begin{array}{l}\text { Median diameter at } \\
\text { breast height }\end{array}$ & dbh.median.2 & stand & $\ldots$ & second & sqrt & $67-370$ & $\mathrm{~mm}$ \\
\hline $\begin{array}{l}\text { Basal area per } \\
\text { hectare }\end{array}$ & BA. 2 & stand & $\ldots$ & second & $\log$ & $30-59$ & $\mathrm{~m}^{2} / \mathrm{ha}$ \\
\hline $\begin{array}{l}\text { Number of trees per } \\
\text { hectare }\end{array}$ & N.2 & stand & $\ldots$ & second & $\log$ & $281-2,780$ & $1 /$ ha \\
\hline pH-value & $\mathrm{pH}$ & $\begin{array}{l}\text { nutrient } \\
\text { supply }\end{array}$ & $\ldots$ & $\ldots$ & $\log$ & $3.5-7.7$ & $\ldots$ \\
\hline $\begin{array}{l}\text { Available water } \\
\text { capacity in the soil }\end{array}$ & AWC & $\begin{array}{c}\text { water } \\
\text { availability }\end{array}$ & $\ldots$ & $\ldots$ & $\log$ & 59-238 & $\mathrm{mm}$ \\
\hline $\begin{array}{l}\text { Mean annual } \\
\text { precipitation sum }\end{array}$ & $\begin{array}{l}\text { P. } 2 \\
\text { P. } 3\end{array}$ & $\begin{array}{c}\text { water } \\
\text { availability }\end{array}$ & annual & $\begin{array}{l}\text { growing } \\
\text { mortality }\end{array}$ & $\begin{array}{l}\log \\
\log \end{array}$ & $\begin{array}{l}959-1,931 \\
978-1,781\end{array}$ & $\mathrm{~mm}$ \\
\hline $\begin{array}{l}\text { Mean precipitation } \\
\text { sum during growing } \\
\text { season }\end{array}$ & $\begin{array}{l}\text { PG.2 } \\
\text { PG.3 }\end{array}$ & $\begin{array}{c}\text { water } \\
\text { availability }\end{array}$ & $\begin{array}{l}\text { growing } \\
\text { season }\end{array}$ & $\begin{array}{l}\text { growing } \\
\text { mortality }\end{array}$ & $\begin{array}{l}\log \\
\text { sqrt }\end{array}$ & $\begin{array}{l}483-1,077 \\
515-1,020\end{array}$ & $\mathrm{~mm}$ \\
\hline $\begin{array}{l}\text { Mean annual air } \\
\text { temperature }\end{array}$ & $\begin{array}{l}\mathrm{mT} .2 \\
\mathrm{mT} .3\end{array}$ & temperature & annual & $\begin{array}{l}\text { growing } \\
\text { mortality }\end{array}$ & $\begin{array}{c}\text { sqrt } \\
\ldots\end{array}$ & $\begin{array}{l}5.3-9.5 \\
5.9-10.2\end{array}$ & ${ }^{\circ} \mathrm{C}$ \\
\hline $\begin{array}{l}\text { Mean air } \\
\text { temperature during } \\
\text { growing season }\end{array}$ & $\begin{array}{l}\text { mTG.2 } \\
\text { mTG.3 }\end{array}$ & temperature & $\begin{array}{l}\text { growing } \\
\text { season }\end{array}$ & $\begin{array}{l}\text { growing } \\
\text { mortality }\end{array}$ & $\begin{array}{l}\log \\
\text { sqrt }\end{array}$ & $\begin{array}{l}10.0-15.1 \\
10.8-15.8\end{array}$ & ${ }^{\circ} \mathrm{C}$ \\
\hline $\begin{array}{l}\text { Mean air } \\
\text { temperature during } \\
\text { winter months }\end{array}$ & $\begin{array}{l}\text { mTW.2 } \\
\text { mTW.3 }\end{array}$ & temperature & winter & $\begin{array}{l}\text { growing } \\
\text { mortality }\end{array}$ & $\begin{array}{l}\ldots \\
\cdots\end{array}$ & $\begin{array}{l}-0.9 \text { to } 2.8 \\
-0.9 \text { to } 3.6\end{array}$ & ${ }^{\circ} \mathrm{C}$ \\
\hline $\begin{array}{l}\text { Mean growing } \\
\text { degree-days }\end{array}$ & $\begin{array}{l}\text { GDD. } 2 \\
\text { GDD. } 3\end{array}$ & temperature & $\begin{array}{l}\text { growing } \\
\text { season }\end{array}$ & $\begin{array}{l}\text { growing } \\
\text { mortality }\end{array}$ & $\begin{array}{l}\log \\
\log \end{array}$ & $\begin{array}{l}1,169-2,150 \\
1,305-2,279\end{array}$ & $\ldots$ \\
\hline $\begin{array}{l}\text { Mean number of } \\
\text { months during } \\
\text { growing season with } \\
\text { water deficit }\end{array}$ & $\begin{array}{l}\text { mDEFdurG. } 2 \\
\text { mDEFdurG. } 3\end{array}$ & $\begin{array}{c}\text { water } \\
\text { availability }\end{array}$ & $\begin{array}{l}\text { growing } \\
\text { season }\end{array}$ & $\begin{array}{l}\text { growing } \\
\text { mortality }\end{array}$ & $\begin{array}{l}\text { logst } \\
\text { logst }\end{array}$ & $\begin{array}{l}0.0-2.5 \\
0.0-2.5\end{array}$ & $\ldots$ \\
\hline $\begin{array}{l}\text { Mean annual } \\
\text { maximum water } \\
\text { deficit }\end{array}$ & $\begin{array}{l}\text { mDEFmax. } 2 \\
\text { mDEFmax.3 }\end{array}$ & $\begin{array}{c}\text { water } \\
\text { availability }\end{array}$ & annual & $\begin{array}{l}\text { growing } \\
\text { mortality }\end{array}$ & $\begin{array}{l}\text { logst } \\
\text { logst }\end{array}$ & $\begin{array}{l}0-17 \\
0-28\end{array}$ & $\mathrm{~mm}$ \\
\hline $\begin{array}{l}\text { Overall maximum of } \\
\text { the annual } \\
\text { maximum water } \\
\text { deficit }\end{array}$ & $\begin{array}{l}\operatorname{maxDEFmax} .2 \\
\operatorname{maxDEFmax} .3\end{array}$ & $\begin{array}{c}\text { water } \\
\text { availability }\end{array}$ & annual & $\begin{array}{l}\text { growing } \\
\text { mortality }\end{array}$ & $\begin{array}{l}\text { logst } \\
\text { sqrt }\end{array}$ & $\begin{array}{l}0-74 \\
0-288\end{array}$ & $\mathrm{~mm}$ \\
\hline $\begin{array}{l}\text { Mean of cumulative } \\
\text { water deficit during } \\
\text { growing season }\end{array}$ & $\begin{array}{l}\text { mDEFcumG. } 2 \\
\text { mDEFcumG.3 }\end{array}$ & $\begin{array}{c}\text { water } \\
\text { availability }\end{array}$ & $\begin{array}{l}\text { growing } \\
\text { season }\end{array}$ & $\begin{array}{l}\text { growing } \\
\text { mortality }\end{array}$ & $\begin{array}{l}\text { logst } \\
\text { logst }\end{array}$ & $\begin{array}{l}0-31 \\
0-35\end{array}$ & $\mathrm{~mm}$ \\
\hline $\begin{array}{l}\text { Overall maximum of } \\
\text { cumulative water } \\
\text { deficit during } \\
\text { growing season }\end{array}$ & $\begin{array}{l}\text { maxDEFcumG. } 2 \\
\text { maxDEFcumG. } 3\end{array}$ & $\begin{array}{c}\text { water } \\
\text { availability }\end{array}$ & $\begin{array}{l}\text { growing } \\
\text { season }\end{array}$ & $\begin{array}{l}\text { growing } \\
\text { mortality }\end{array}$ & $\begin{array}{c}\text { logst } \\
\text { sqrt }\end{array}$ & $\begin{array}{l}0-152 \\
0-351\end{array}$ & $\mathrm{~mm}$ \\
\hline $\begin{array}{l}\text { Percentage of years } \\
\text { with at least } \\
1 \text { month water } \\
\text { deficit }\end{array}$ & $\begin{array}{l}\text { percDEF.2 } \\
\text { percDEF.3 }\end{array}$ & $\begin{array}{c}\text { water } \\
\text { availability }\end{array}$ & annual & $\begin{array}{l}\text { growing } \\
\text { mortality }\end{array}$ & $\begin{array}{l}\text { logst } \\
\text { logst }\end{array}$ & $\begin{array}{l}0-100 \\
0-100\end{array}$ & $\%$ \\
\hline
\end{tabular}

Notes: Note the varying seasonal level of the covariates considering the entire year, the growing season from April to September $(G)$ and the winter month January to March $(W)$. All climatic covariates were calculated for both the growth (2) and the mortality period (3). The stand covariates were derived for the second inventory of each record (2). The transformation (log/logst, square root or none, as applicable) that resulted in the best performance is indicated. All covariates were included as an additional term and in interaction with logst $(\mathrm{relB} A I)$. 
operating characteristic curve $(A U C)$ were used to examine model performance in more detail. $p_{\text {bias }}$, which indicates calibration accuracy, is defined as the difference of the mean predicted mortality probability (simulated mortality) $\bar{p}_{\Delta t=10}$ and the mean mortality rate (observed mortality) $\bar{y}_{\Delta t=10}$ over a time period of $10 \mathrm{yr}$ (cf. Appendix S2). $A U C$ is a widely used, threshold-independent measure of classification accuracy (Hosmer and Lemeshow 2005). In our models, it corresponds to the probability that the model predicts a larger mortality probability for a randomly chosen dead tree than for a randomly chosen living tree (Fawcett 2006). AUC ranges between 0 and 1 and equals 0.5 for randomly assigned tree status. Following Hosmer and Lemeshow (2005), the discriminative ability can be rated as acceptable $(0.7 \leq A U C<0.8)$, excellent $(0.8 \leq A U C<0.9)$, or outstanding $(A U C \geq 0.9)$.

$P_{\text {bias }}$ and $A U C$ were calculated for the entire datasets as well as for a range of subsets by applying the models calibrated with the full data to individual reserves and specific diameter classes. This in-depth analysis provides further information on the variability of model performance.

\section{Calibration and validation scheme}

Based on the reduced Swiss dataset, the importance of environmental and stand characteristics for the prediction of tree mortality was assessed using 10-fold crossvalidation and the one standard error rule to avoid over-fitting (cf. Appendix S2 for further details; Breiman et al. 1984, Hastie et al. 2001). A basic model comprising $\log (d b h), \operatorname{logst}(r e l B A I)$, and their interaction was compared with more sophisticated models, each additionally including one environmental or stand characteristic and its interaction with relBAI.

Since to our surprise no considerable benefit of including environmental and stand characteristics was found, the dataset for Switzerland was expanded to all beechdominated reserves (Table 1). For each of the datasets from Switzerland, Germany, and Ukraine, 10-fold crossvalidation with a modified selection criterion resulting in less simplified models (cf. Appendix S2) was applied to select an optimal combination of covariates and their respective transformations. Terms considered in the model formulae were $\log (d b h)$ and $\operatorname{logst}($ relBAI). Additionally, the quadratic terms of the transformed variables and the interaction of $\log (d b h)$ and $\operatorname{logst}(\mathrm{relB} A I)$ were included (Appendix S1: Table S2). A comprehensive assessment of model performance was carried out for the models that achieved high discriminative accuracy. Additionally, each model was validated with data from the inventory datasets that had not been used for its calibration (Table 4).

All computations were performed within $\mathrm{R}$ ( $\mathrm{R}$ Core Team 2015). relBAI was transformed using logst() from the package regro ( $\mathrm{R}$ package version $1.0-4 / \mathrm{r} 46)$. Maximum likelihood estimation was carried out using the function optim() with the fitting method BFGS. AUC calculations were based on the function $a u c()$ from the package SDMTools (R package version 1.1-221). Since auc() prevents values below 0.5 , which is not appropriate for $A U C$ calculations using partial datasets, the corresponding part of the code was removed.

\section{RESULTS}

\section{Environmental and stand influences on mortality}

The results of the 10-fold cross-validation revealed no considerable model improvement by any of the environmental and stand characteristics (Appendix S1: Figure S3). Twenty-nine out of 31 covariates resulted in an improved $B S$, most strongly by mean and median $d b h$, winter temperature, and stem density, whereas $\mathrm{pH}$ and BA did not cause a decrease in $B S$. The best model included median $d b h$ as an additional covariate. In spite of these improvements, mean $B S$ of the basic model without additional variables was still below the limit of the one standard error rule, i.e., the mean $B S$ plus the standard error of $B S$ of the best model (cf. Appendix S2). Consequently, none of the additional covariates can be expected to substantially improve mortality predictions. To avoid the risk of over-fitting, the model including $d b h$, relBAI, and their interaction was selected as the best parsimonious model, and subsequent models did not include additional environmental or stand variables.

\section{Mortality patterns}

The model selection procedure for the datasets from Switzerland, Germany, and Ukraine resulted in three different model shapes (Table 3; for the results of model selection cf. Appendix S1: Table S2). Beech mortality in the Swiss reserves was best described by the combination of $\log (d b h), \operatorname{logst}(\mathrm{relB} A I)$, the quadratic term of $\log$ $\operatorname{st}(r e l B A I)$, and the interaction of $d b h$ and relBAI. In Germany, the interaction and the quadratic term were not required, thus resulting in a simpler model based on $\log (d b h)$ and $\operatorname{logst}(r e l B A I)$. In Ukraine, tree growth was not required to predict tree mortality, but models including a quadratic term for $\log (d b h)$ achieved highest accuracy. Thus, the most parsimonious model for the Ukrainian data included only $\log (d b h)$ and its quadratic term.

For a beech tree with median growth, the probability to die within $10 \mathrm{yr}$ ranged between $1 \%$ and $32 \%$ depending on its $d b h$, with considerable differences between the three models (Fig. 1). In the Swiss and German reserves, the mortality probability for beech was highest for small, slow-growing trees and decreased with increasing $d b h$ and relBAI. However, the effect of growth on the mortality probability was less pronounced for the German model. Still, the Swiss and the German model predicted similar mortality probabilities over the entire $d b h$ range for trees with average growth. In the Ukrainian forest, mortality patterns differed from those in the Swiss and German reserves. While the mortality probability similarly decreased with $d b h$ for small trees, the risk of death increased again for trees with a $d b h>25 \mathrm{~cm}$. The resulting 
TABle 3. Parameter estimates, standard errors (SE), significance levels (*** $P \leq 0.001, * * P \leq 0.01, * P \leq 0.05$ ), and confidence intervals of the calibrated models for Switzerland, Germany, and Ukraine.

\begin{tabular}{|c|c|c|c|c|c|c|}
\hline Coefficient & $\beta$ & $S E$ & $t$ & $P$ & Significance & $\begin{array}{l}\text { Confidence } \\
\text { intervals }\end{array}$ \\
\hline \multicolumn{7}{|l|}{ Switzerland } \\
\hline Intercept & -0.204 & 0.816 & -0.25 & 0.802 & & {$[-1.80,1.40]$} \\
\hline $\log (d b h)$ & -2.302 & 0.141 & -16.36 & 0.000 & $* * *$ & {$[-2.58,-2.03]$} \\
\hline logst (relBAI) & -1.922 & 0.482 & -3.99 & 0.000 & $* * *$ & {$[-2.87,-0.98]$} \\
\hline$(\operatorname{logst}(\operatorname{relBAI}))^{2}$ & -0.698 & 0.078 & -8.95 & 0.000 & $* * *$ & {$[-0.85,-0.55]$} \\
\hline $\log (d b h) \times \operatorname{logst}($ relBAI $)$ & -0.616 & 0.057 & -10.74 & 0.000 & $* * *$ & {$[-0.73,-0.50]$} \\
\hline \multicolumn{7}{|l|}{ Germany } \\
\hline Intercept & 0.917 & 0.592 & 1.55 & 0.122 & & {$[-0.24,2.08]$} \\
\hline $\log (d b h)$ & -1.281 & 0.086 & -14.97 & 0.000 & $* * *$ & {$[-1.45,-1.11]$} \\
\hline $\operatorname{logst}($ relBAI) & -0.537 & 0.084 & -6.36 & 0.000 & $* * *$ & {$[-0.7,-0.37]$} \\
\hline \multicolumn{7}{|l|}{ Ukraine } \\
\hline Intercept & 14.201 & 3.708 & 3.83 & 0.000 & $* * *$ & {$[6.93,21.47]$} \\
\hline $\log (d b h)$ & -6.859 & 1.380 & -4.97 & 0.000 & $* * *$ & {$[-9.56,-4.15]$} \\
\hline $\log (d b h)^{2}$ & 0.625 & 0.125 & 5.02 & 0.000 & $* * *$ & {$[0.38,0.87]$} \\
\hline
\end{tabular}

Notes: The transformation threshold $c$ for the logst-transformation of relBAI was calibrated to the combined relBAI values of Switzerland, Germany, and Ukraine $(\mathrm{c}=0.002333)$. Abbreviations are $d b h$, diameter at breast height $(\mathrm{mm})$ and relBAI, annual relative basal area increment.

U-shaped relationship between $d b h$ and mortality probability was independent of tree growth.

\section{Internal performance of mortality models}

All three models predicted nearly unbiased overall mortality rates, as indicated by $p_{\text {bias }}$ of approximately zero, thus confirming successful calibration (Table 4). According to the criteria by Hosmer and Lemeshow (2005), the Swiss model achieved excellent discrimination with an $A U C$ of 0.83 . The discriminative power of the German model was acceptable $(A U C=0.79)$, while the Ukrainian model performed only somewhat better than a random mortality

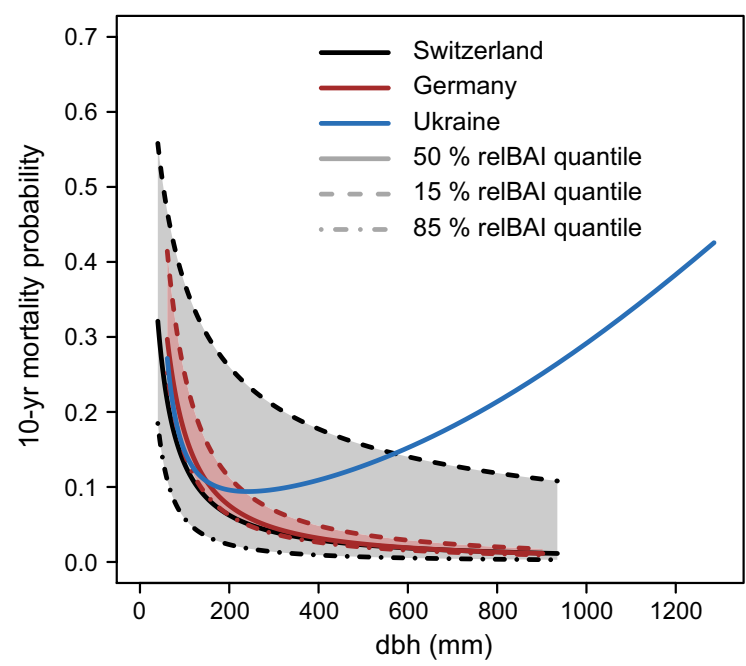

FIG. 1. Simulated 10-yr mortality probability as a function of $d b h$ for three growth levels as predicted by the Swiss, German, and Ukrainian models. Median and quantiles at $15 \%$ and $85 \%$ of annual relBAI were selected based on the combined relBAI values of all three datasets: median, $0.012 ; 15 \%$ quantile, 0.002 ; $85 \%$ quantile, 0.028 . Predictions are restricted to the available $d b h$ range of each dataset to avoid extrapolation. assignment $(A U C=0.60)$. Therefore, only the performance of the Swiss and the German model, which attained sufficient discrimination of living and dead trees, was analyzed in more detail for their calibration domain.

The discriminative ability of the models clearly varied with tree size (Fig. 2). The Swiss model best distinguished between dead and living trees of small to medium size, whereas the death of trees with a $d b h>35 \mathrm{~cm}$ was predicted less successfully. This pattern was only partially evident for the German model with a lower overall discriminative power. Again, trees with diameters between 30 and $50 \mathrm{~cm}$ featured lower $A U C$ values than smaller trees. However, unlike the Swiss model, the German model was able to discriminate acceptably between living and dead trees with a $d b h>50 \mathrm{~cm}$. The discriminative power of the two models was influenced not only by tree size, but it also differed considerably among the reserves (Appendix S1: Table S3). For the Swiss dataset, $A U C$ values in the range 0.71-0.94 indicated acceptable to outstanding discrimination. In Germany, the model achieved acceptable to excellent performance for most of the reserves $(A U C=$ $0.74-0.89$ ), but the discrimination of living and dead trees was unsatisfactory in three reserves $(A U C<0.7)$.

To assess the influence of tree size on $p_{\text {bias }}$, observed and simulated mortality rates were analyzed as a function of $d b h$ (Fig. 3), revealing that the Swiss and the German models predicted consistent mortality rates over the entire $d b h$ range when considering the full dataset (Fig. 3a, b). However, $p_{\text {bias }}$ for single reserves varied between $-8.0 \%$ and $3.7 \%$ in Switzerland and between $-8.6 \%$ and $4.3 \%$ in Germany (Appendix S1: Table S3). Positive and negative $p_{\text {bias }}$ values were caused by deviations of observed and simulated mortality rates in all diameter classes, without any tree size tending to show a particularly large mismatch (Fig. $3 \mathrm{c}-\mathrm{h}$ ). Only the $p_{\text {bias }}$ pattern of the German reserve Sonnenkopf (Fig. 3f) showed increased mortality of trees $>50 \mathrm{~cm}$ that was not captured by the model. 
TABLE 4. Calibration and validation performance of the Swiss, German, and Ukrainian models.

\begin{tabular}{|c|c|c|c|c|c|}
\hline \multirow[b]{2}{*}{ Calibration dataset } & \multirow[b]{2}{*}{ Performance criterion } & \multirow{2}{*}{$\begin{array}{l}\text { Performance of } \\
\text { calibration dataset }\end{array}$} & \multicolumn{3}{|c|}{ Performance of external evaluation } \\
\hline & & & Switzerland & Germany & Ukraine \\
\hline Switzerland & $\begin{array}{c}p_{\text {bias }}(\%) \\
\text { AUC }\end{array}$ & $\begin{array}{r}-0.23 \\
0.83\end{array}$ & $\ldots$ & $\begin{array}{l}3.45 \\
0.76\end{array}$ & $\begin{array}{r}-8.00 \\
0.54\end{array}$ \\
\hline Germany & $\begin{array}{l}p_{\text {bias }}(\%) \\
A U C\end{array}$ & $\begin{array}{r}-0.10 \\
0.79\end{array}$ & $\begin{array}{r}-0.57 \\
0.79\end{array}$ & $\ldots$ & $\begin{array}{r}-5.71 \\
0.51\end{array}$ \\
\hline Ukraine & $\begin{array}{l}p_{\text {bias }}(\%) \\
A U C\end{array}$ & $\begin{array}{l}0.00 \\
0.60\end{array}$ & $\begin{array}{l}0.20 \\
0.68\end{array}$ & $\begin{array}{l}5.75 \\
0.63\end{array}$ & $\begin{array}{l}\ldots \\
\ldots\end{array}$ \\
\hline
\end{tabular}

Note: The respective performance measures 10 -yr $p_{\text {bias }}$ and $A U C$ were calculated for the calibration dataset and additionally when each of the three models was applied to the datasets of the two other countries (external evaluation) to assess the transferability of the mortality models.

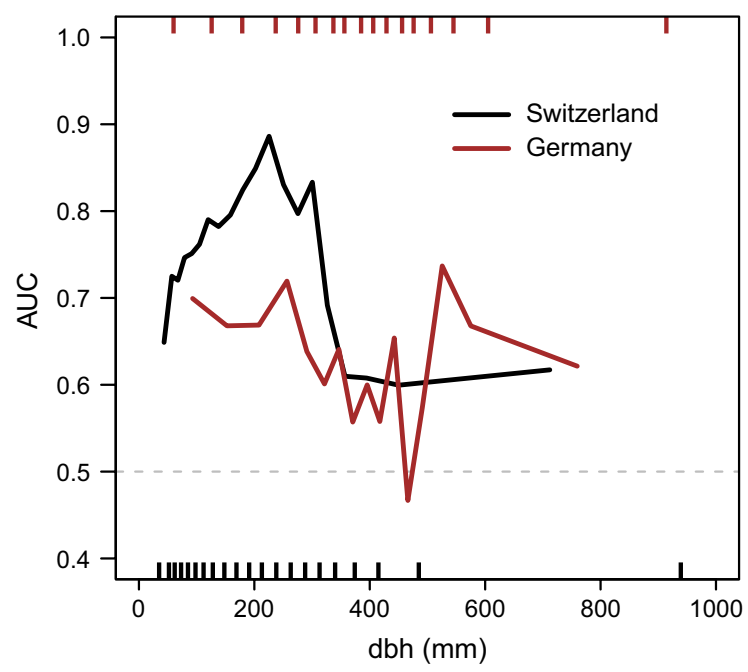

FIG. 2. AUC values for the Swiss and the German model calculated separately for $d b h$ classes of the respective calibration dataset to assess the influence of tree size on discriminative power. The $d b h$ classes are approximately equally sized (Switzerland, $n_{\text {classes }}=20$; Germany, $n_{\text {classes }}=16$ ). The limits of the $d b h$ classes for both datasets are indicated as rugs in the respective color. The gray dashed line at $A U C=0.5$ indicates a discrimination as good as random mortality assignment.

\section{External evaluation of mortality models}

When the Swiss and the German model were validated against each other, $A U C$ values of both models indicated acceptable discriminative power (Table 4). However, when validated with the Ukrainian data, both models achieved very poor $A U C$ values. In contrast, the Ukrainian model was more successful in discriminating living vs. dead trees for the German and the Swiss dataset than within its calibration domain.
The analysis of $p_{\text {bias }}$ as a function of tree size (Fig. 4, cf. Table 4 for overall $p_{\text {bias }}$ values) revealed that mortality rates in the Swiss reserves were reproduced quite well by the German model, showing only a weak underestimation for average-sized and large trees, thus resulting in an overall $p_{\text {bias }}$ value close to 0 . In contrast, the Swiss model was less successful in predicting mortality rates for the German dataset, especially for small and averagesized trees, resulting in an overestimation of mortality $\left(p_{\text {bias }}=3.45 \%\right)$. The U-shaped mortality pattern in the Ukrainian model resulting from the quadratic term of $d b h$ caused a clear overestimation of mortality for larger trees in the Swiss as well as in the German datasets. Vice versa, when the Swiss and the German model were used to predict mortality rates for the Ukrainian dataset, the mortality of large trees was far too low.

\section{DiscusSION}

\section{Environmental and stand influences on mortality}

The integration of covariates beyond tree growth and size in tree mortality models to improve their accuracy and applicability to variable site conditions has been suggested in a number of studies (e.g., Monserud and Sterba 1999, Dietze and Moorcroft 2011), but these conjectures could not be tested due to insufficient sample sizes. For the first time we were able to evaluate this using a very large dataset for a widespread European tree species. Contrary to expectations (cf. Nothdurft 2013, Neuner et al. 2015), none of the environmental or stand variables markedly enhanced the accuracy of mortality predictions. Nevertheless, this does not mean that environmental and stand characteristics do not influence beech mortality, but rather that our models consider these effects via the integrating variable growth. In addition, it should be taken into account that our dataset does not

FIG. 3. Observed and simulated 10-yr mortality rates of the Swiss and the German model plotted as a function of $d b h$ to assess the influence of tree size on the prediction bias. $(\mathrm{a}, \mathrm{b})$ Mortality rates are shown for the full datasets as well as for $(\mathrm{c}-\mathrm{h})$ three typical example reserves with under- and overestimation and with a nearly unbiased overall mortality prediction to reveal which tree sizes resulted in substantial $p_{\text {bias }}$ values. For each sub-plot, the number of records $(n)$ included in the respective dataset and the performance measures $A U C$ and $p_{\text {bias }}$ are indicated. The $d b h$ classes are approximately equally sized with $n_{\text {classes }}=10$. The limits of the $d b h$ classes for both datasets are indicated as rugs in the respective color. 


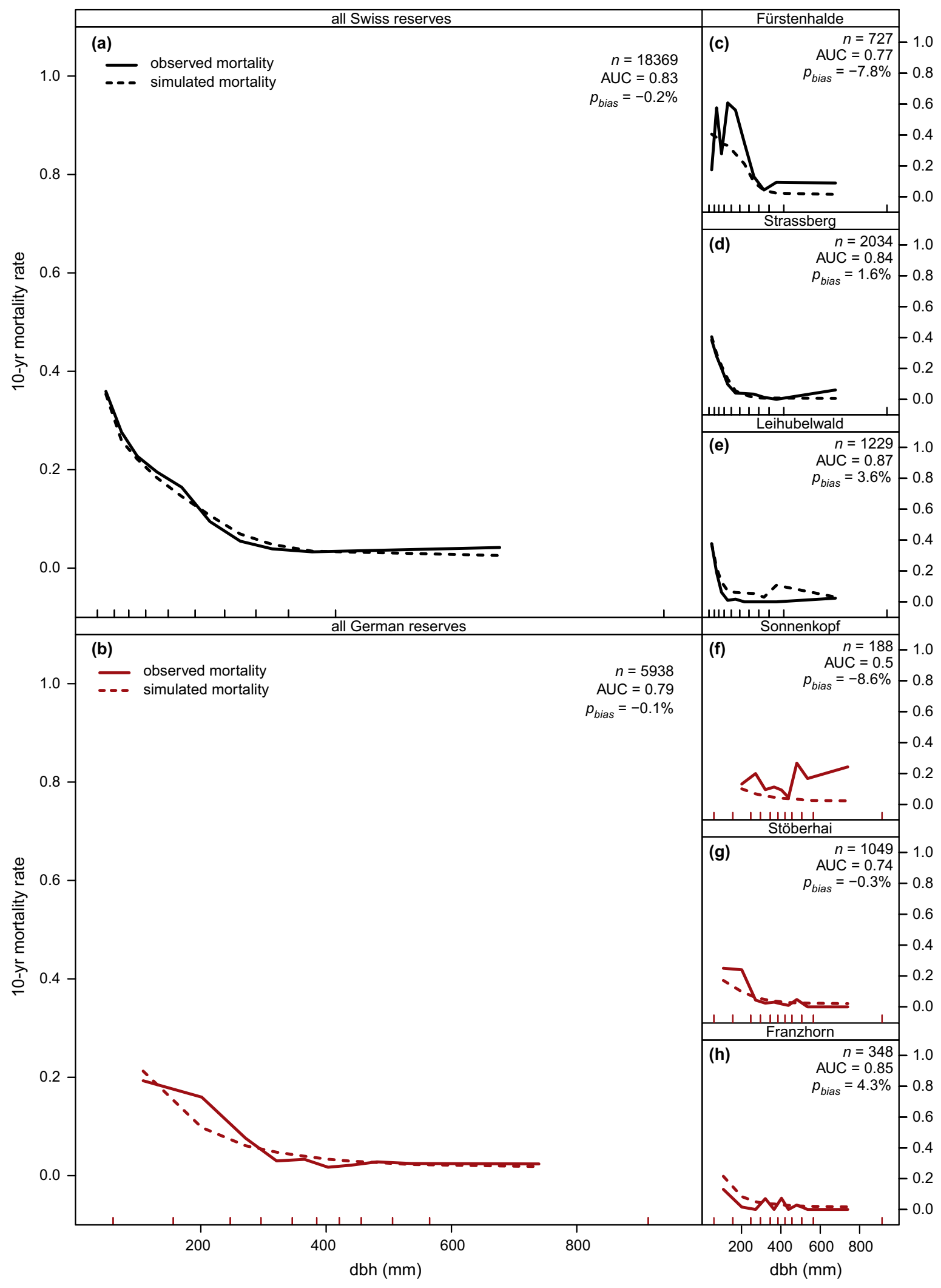




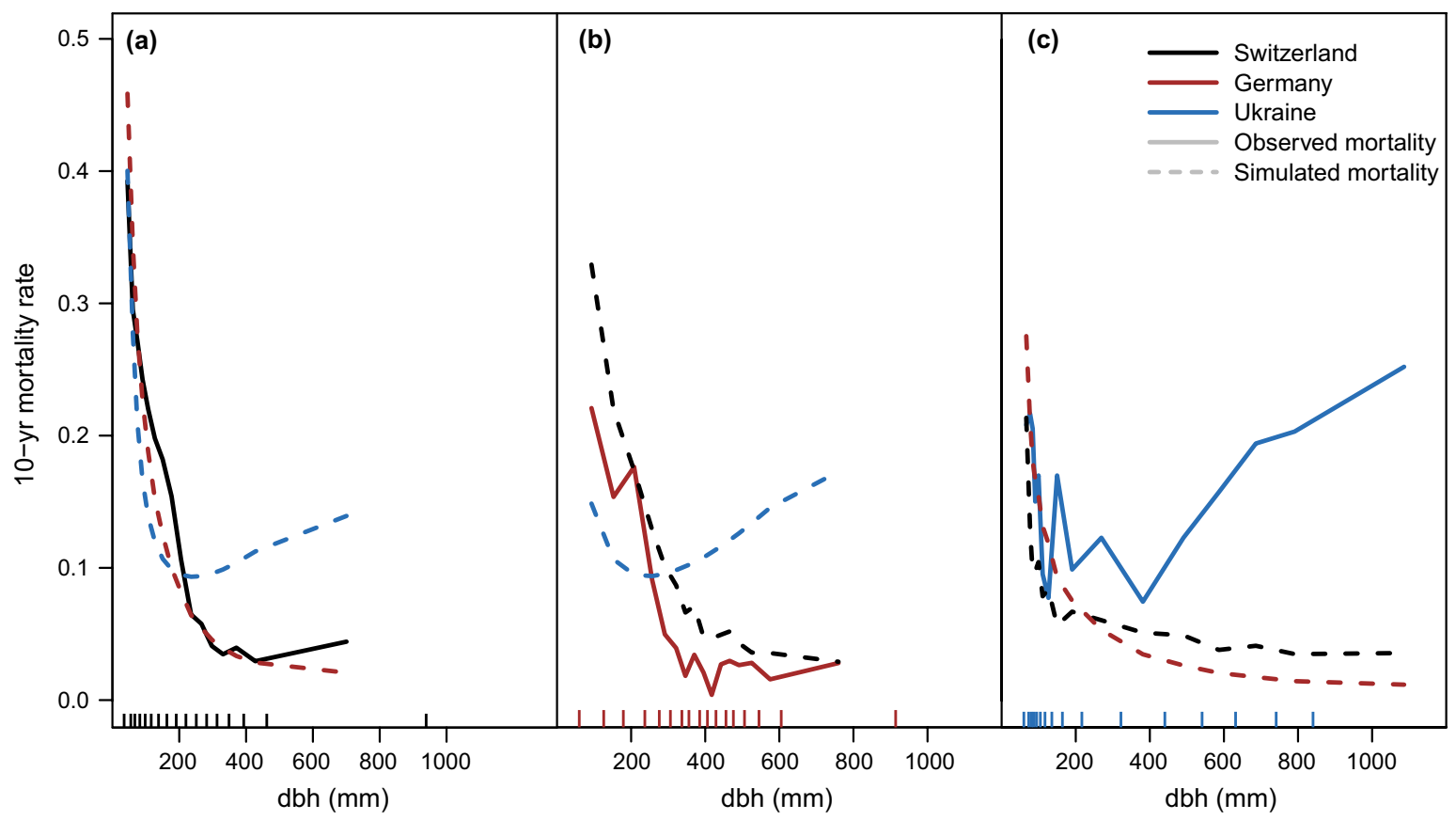

FIG. 4. Ten-year mortality rates as the result of external validation plotted as a function of $d b h$ for the datasets from (a) Switzerland, (b) Germany, and (c) Ukraine. Observed mortality is shown with solid lines, mortality simulated by models of the respective other countries is shown in dashed lines. The $d b h$ classes are approximately equally sized $\left(n_{\text {classes }}=16\right)$. The limits of the $d b h$ classes for the datasets are indicated as rugs in the respective color.

feature annual resolution, i.e., the lack of model improvements when including climate and drought variables may be due to the inability to detect impacts of climate or competition over shorter time scales (Dobbertin 2005). Because of their high temporal resolution, dendrochronological data are likely to have higher potential for contributing to the understanding of the interactions between environment, growth, and tree mortality (e.g., Bigler et al. 2004, Gillner et al. 2013, Cailleret et al. 2016). Also, the lack of any direct influence of environmental covariates on mortality in our models may partly have been caused by the low spatial resolution of the climatic and especially the soil data, such that these covariates did not effectively represent drought conditions at the tree level.

Growth, which integrates not only the effects of competition, but also those of the environment (Dobbertin 2005) was not considered as a covariate in the models by Nothdurft (2013) and Neuner et al. (2015). Conversely, in none of the growth-based beech mortality models (e.g., Dursky 1997, Wunder et al. 2008, Holzwarth et al. 2013) the influence of climate, soil, or competition was taken into account. Our novel approach combines growth and environmental data in unified models, indicating that tree size $(d b h)$ and stem growth (relBAI) sufficiently integrate the adverse effects of water availability and competition on the vitality of beech, and that the influence of growth on mortality is stable even under varying environmental conditions. We expect our results to be reliable since the Swiss reserves cover a large portion of the natural gradient of site characteristics for beech forests, encompassing dry to moist and warm to cool conditions (Table 2), and yet not even drought, which we consider as the environmental driver with the largest potential to influence the growth-mortality relationship (Geßler et al. 2007), explained spatial and temporal differences of mortality. Thus, we suggest $d b h$ and relBAI as meaningful and unifying predictors of beech mortality based on inventory data with decadal resolution.

\section{Mortality patterns}

The similarities in mortality predictions of the Swiss and the German model indicate that mortality processes were similar in pattern and magnitude in the reserves of both networks. Thus, mortality was driven mainly by competition, and the competitive status and vitality of a tree could be expressed well using tree size and growth. This is in line with mortality relationships for beech found in Swiss reserves (Wunder et al. 2007, 2008), in a nature reserve in Eastern Germany (Gillner et al. 2013) and in the German National Park Hainich (Holzwarth et al. 2013). In contrast to Holzwarth et al. (2013), however, we did not find a U-shaped mortality relationship between $d b h$ and mortality, most presumably due to the low importance of advanced decay phenomena in the reserves of our dataset as a result of previous management and their comparatively low age (Heiri et al. 2011, Meyer and Schmidt 2011).

In contrast to the comparable influence of tree size on mortality probability, the growth variable relBAI more 
strongly affected mortality in the Swiss than in the German reserves. This may be related to (1) different climatic conditions, (2) differences in species composition, and/or (3) differences in stand structure and competition. However, we decided not to include further site and stand covariates into these models since, when doing so for the reduced Swiss dataset, no marked model improvement was achieved.

Although the climate of the Swiss and German reserves is similar, mean annual precipitation sums are higher in Switzerland, potentially contributing to the different relationship between growth and mortality (Monserud and Sterba 1999). Under better growing conditions, which may apply to the Swiss reserves, the same reduction in growth could lead to a larger increase of mortality risk than under less favorable conditions, where trees are adapted to lower growth. However, we demonstrated that climate and drought could not explain the variability in beech mortality for a subset of the Swiss data.

Species composition was found to be related to beech mortality (Jutras et al. 2003, Boeck et al. 2014, Neuner et al. 2015). Possibly, the higher proportion of spruce and fir in the Swiss reserves may explain the pronounced effect of low growth on mortality. However, the quantification of such effects is everything but straightforward and should be based on spatially explicit, species-specific competition indices.

Lower BA, $N$, and $S D I$ in the German reserves suggest lower competition compared to the Swiss reserves. Although a trend of increasing importance of tree growth for mortality in denser stands (i.e., higher BA) was confirmed within both datasets, no marked improvement resulted when $\mathrm{BA}$ or an interaction of $\mathrm{BA}$ and relBAI were included in a model for the combined Swiss and German data (results not shown). This suggests that slower growth is less important in stands with lower density, such as in the German reserves, but the processes altering the influence of growth on mortality are not sufficiently explained with stand density alone. Differences in mortality may originate from the type of management regime prior to reserve designation (i.e., in Germany mainly thinning from below) and the time since the last management intervention, factors that are not evident directly from stand structural attributes.

Compared to the Swiss and German mortality models, the Ukrainian model reflected entirely different mortality patterns. The U-shaped size-dependent mortality and the absence of any influence of growth on mortality were most striking. High mortality rates for small as well as for large trees have long been proposed as a general pattern (Buchman et al. 1983, Lorimer and Frelich 1984) and have recently been disentangled into different mortality modes, thus providing improved insights on the mechanisms associated with beech mortality (Holzwarth et al. 2013). Our findings coincide with this mortality pattern, as processes that may act to amplify the mortality of large trees, such as stem rot or wind breakage, were reported for the Uholka forest (Trotsiuk et al. 2012, Hobi et al.
2015). This may have been the cause for the lack of a growth-related component in the mortality model, i.e., also trees with high growth rates may have died.

However, it should be taken into account that the Uholka data derive from one single (albeit large) plot monitored during $10 \mathrm{yr}$, whereas the German and Swiss data cover not only a much larger set of environmental conditions but also a much longer period. Thus, conclusions derived from this single plot with only one mortality period should be drawn with care, as mortality is highly variable in space and time (cf. Wunder et al. 2008). Still, several lines of evidence indicate that it may be representative of primeval beech forests in general, including the U-shaped mortality pattern in the German National Park Hainich (Holzwarth et al. 2013) and the high amounts of deadwood in all decay stages in the UholkaShyrokyi Luh primeval beech forest, indicating regularly occurring small-scale disturbances (Hobi et al. 2015).

\section{Internal performance of mortality models}

The good to excellent overall discriminative performance achieved by the German and Swiss models substantiates the suitability of tree size and growth for the prediction of natural mortality of beech. In comparison, the Ukrainian model performed much worse. Besides the additional source of variability due to wind disturbances, it is possible that tree mortality in primeval forests can generally be described less accurately by size and growth due to the concurrence of all successional stages. The considerable variation in individual tree growth histories (Nagel et al. 2014) and increased susceptibility of trees to factors that are hard to predict, such as stem rot or other diseases, may render the process of tree mortality and the relationship between vigor, competitiveness, and mortality more complex (Franklin et al. 1987).

Owing to the large number of records included in our datasets, the performance criteria $A U C$ and $p_{\text {bias }}$ could be calculated not only for the entire dataset, but also (1) as a function of tree size and (2) for individual reserves. Both elements provide novel insights.

On the one hand, $A U C$ patterns indicate that the high overall model performance was driven particularly by the excellent discrimination of small- to mid-diameter trees, while the predictive power of the covariates available in our study decreased with tree size. This suggests that competition was the main driver for beech mortality as captured in the Swiss and German mortality model. Competition decreases in importance for larger trees (Franklin et al. 1987), but it is reasonable to surmise that mortality of large trees is more complex and thus harder to predict as the result of, e.g., wind, pathogens, and wood-decaying fungi (Trotsiuk et al. 2012, Holzwarth et al. 2013). Additionally, mortality processes for such trees may not be covered well in our datasets due to the comparatively small number of trees with $d b h>50 \mathrm{~cm}$.

On the other hand, the performance criteria calculated separately for each reserve revealed large differences in 
predictive, as well as discriminative, ability. In combination with the graphical representation of observed and simulated mortality over $d b h$, performance measures calculated per reserve allowed us to relate the influence of development stage and disturbance to the observed mortality patterns. For example, the underestimation of the mortality of trees with $d b h>50 \mathrm{~cm}$ in the German reserve Sonnenkopf (Fig. 3f) was possibly caused by a small-scale wind disturbance (Meyer et al. 2015). However, this was the only example where an under- or overestimation of mortality could be related to a particular historical event. Similarly, it was not possible to group the reserves according to $p_{\text {bias }}$ patterns, and the variability in mortality patterns at the level of individual permanent plots could not be linked to climate, soil, or stand structure, either. Thus, tree mortality remains a highly variable and multi-factorial process.

\section{External evaluation of mortality models}

Validation with independent data is an important step to rigorously test the transferability of mortality models, e.g., for application in DVMs (Hawkes 2000, Woolley et al. 2012), be it at the species level (stands and landscapes) or for generalization into a broad suite of plant functional types (global level). To assess the general applicability of a model, the importance of the performance measures $A U C$ and $p_{\text {bias }}$ should be weighted differently than in an internal assessment. $p_{\text {bias }}$ should be evaluated first since it is more sensitive to under- and overestimation of mortality rates than the discrimination measure $A U C$. However, overall $p_{\text {bias }}$ values are only helpful if the mortality pattern across tree size is reflected adequately (cf. Table 4, Fig. 4; Ukrainian model applied to Swiss data). Thus, it is important to graphically represent the observed and simulated mortality rates as a function of tree size.

The limited informative value of $A U C$ regarding validation performance is clearly evident from the Ukrainian model, which better discriminated living and dead trees for the Swiss and German datasets than for its own calibration data. Thus, the discriminative power of a model strongly depends on the dataset to which it is applied, and hence $A U C$ values reported for validation are primarily an indicator of the discrimination of dead vs. living trees in the dataset itself, and only secondarily of the general suitability of model structure and parameterization.

$P_{\text {bias }}$ from the external validation reflected the mortality patterns identified by the three mortality models, showing similarities for the Swiss and the German networks but a deviating pattern for the Ukrainian forest. Due to the increased mechanical instability of larger trees in the Ukrainian forest, the models calibrated with data from Swiss and German reserves were not transferable to the Ukrainian data, and vice versa. The overestimation of mortality by the Swiss model when applied to German data traces back to the larger effect of tree growth on mortality in the Swiss model, which penalized more strongly for low relBAI values and thus reduced the survival of slow-growing trees. Still, the low $p_{\text {bias }}$ values of
$3.33 \%$ and $-0.53 \%$ for a period of $10 \mathrm{yr}$ and acceptable $A U C$ s suggest that the similarities of mortality patterns in Switzerland and Germany allow for a meaningful application of the models to the other country or the derivation of a joint model based on the combined datasets.

\section{Implications for mortality algorithms in DVMs}

A major limitation for the analysis of long-term forest processes such as mortality is data availability (Bugmann 1996, Hawkes 2000). Generalized logistic regression is helpful to make effective use of inventory data from permanent plots of forest reserves for mortality modeling, even in the case of irregular measurement intervals. Although we found that the bias in mortality predictions introduced by ignoring the dependency structure is negligible (cf. Appendix S1: Figure S2), the approach of generalized logistic regression could be further improved by including random effects to account for the hierarchical data structure (Yang and Huang 2013). Empirical mortality models are strongly needed to improve projections of DVMs (Adams et al. 2013). However, the derivation of such predictive models requires different strategies for (1) model selection and (2) performance assessment compared to mortality models that are built for inferring the effects of a set of covariates on mortality.

Models designed for mortality prediction in DVMs should be based on a model selection procedure that avoids the risk of over-fitting, which can be particularly problematic when a mortality model is derived from a spatially and/or temporally limited dataset. We used a very large dataset and ensured model parsimony by applying a 10-fold cross-validation combined with the one standard error rule (Breiman et al. 1984).

The combined analysis of $p_{\text {bias }}$ and $A U C$ enables a comprehensive screening of the performance of tree mortality models in terms of calibration and discrimination. In particular, it provides insights on often neglected aspects of spatial variability and validity and thus provides essential information regarding the uncertainty of mortality algorithms in DVMs. We suggest that $p_{\text {bias }}$ and $A U C$ should be preferred over confusion matrices or sensitivity and specificity; threshold-dependent metrics should be avoided since they strongly depend on the choice of the threshold (Lawson et al. 2014). Moreover, thresholds are not required for the implementation of mortality algorithms in DVMs when stochastic approaches are employed, which were found to be more promising for the classification of tree status than deterministic approaches (Fortin and Langevin 2011, Bircher et al. 2015). Thus, we suggest $A U C$ as a key measure to assess the calibration performance while $p_{\text {bias }}$ and its graphical representation as a function of tree size should be used to characterize validation performance. For internal performance assessments based on subsets of the calibration data, a combination of both performance criteria is recommended to assess the spatial variability of mortality. We also recommend the analysis of $A U C$ 
patterns that are calculated by $d b h$ class, thus revealing the accuracy of predictions for different tree sizes.

The mortality models presented here were derived with a view towards the requirements of DVMs, i.e., assuring parsimony and that their internal as well as external performance was evaluated comprehensively. Acceptable $p_{\text {bias }}$ and high $A U C$ values show that these models allowed us to approximate tree mortality reasonably well by simple indicators of tree size and growth. Rather simple relationships of log-transformed covariates and their quadratic equivalent successfully described the covariate effect on mortality and make our models easily applicable. Nevertheless, potential model improvements by means of more flexible approaches, e.g., restricted cubic splines (Wunder et al. 2008), could be assessed in the future. External model evaluation suggested rather accurate mortality predictions for the German and the Swiss mortality models when validated with data from the respective other country. Moreover, model robustness was fostered by the largest dataset ever used to calibrate beech mortality models, covering a wide range of environmental conditions and multiple decades. Therefore, the Swiss and German mortality models are promising candidates for inclusion in DVMs.

Dynamic vegetation models are widely used to anticipate future ecosystem development based on climate scenarios (Bonan 2008). Although the mortality models developed here do not include climate variables explicitly, mortality depends on the growth variable relBAI, which itself responds to interannual variability in the environment, including climate. However, growth rates as simulated in a DVM may not have the same features as those from inventory or tree-ring data, e.g., regarding the absolute level of simulated growth, the magnitude of interannual variability, or temporal autocorrelation (cf. Rasche et al. 2012, Anderegg et al. 2015). Thus, the interaction of growth and mortality predictions warrants further scrutiny before simulated growth can be reliably used as a predictor for tree mortality (Wernsdörfer et al. 2008, Larocque et al. 2011, Radtke et al. 2012, Bircher et al. 2015). Nevertheless, the growth-dependent mortality algorithms derived here are advantageous for implementation in DVMs as they follow the rule of parsimony and avoid undesirable interactions of climatedependent growth and additional climate variables.

In conclusion, we developed models for regular mortality of individual beech trees that we can recommend for incorporation and examination in DVMs. They are highly promising for pushing the frontier of DVM development towards more reliable predictions that are congruent with observational data (Bircher et al. 2015). However, for an adequate parameterization, mortality models for an extended set of tree species are required, taking into account their widely different life history strategies (Franklin et al. 1987). We are confident that such models can be fitted and evaluated using the methodology developed here, provided that extensive datasets covering large gradients of site conditions are available. The limited availability of such data continues to constrain the development of robust models of crucial forest processes such as tree mortality and recruitment (Lutz 2015). Thus we need to emphasize the invaluable nature of long-term monitoring data in the context of a growing need for better empirical foundations in the modeling of future vegetation dynamics.

\section{ACKNOWLEDGments}

This study was funded by the Swiss National Science Foundation project "Predicting growth-dependent tree mortality: a key challenge for population ecology" (grant no. 31003A_140968). The funding by the Swiss Federal Office of the Environment for data acquisition is gratefully acknowledged. The authors would like to thank Roger Köchli for intensive field work, Pascale Weber for providing additional soil data, Nicolas Bircher for handling and processing the climate data, and Andreas Ruckstuhl and Jürgen Zell for valuable statistical support.

\section{Literature Cited}

Adams, H. D., A. P. Williams, C. Xu, S. A. Rauscher, X. Jiang, and N. G. McDowell. 2013. Empirical and process-based approaches to climate-induced forest mortality models. Frontiers in Plant Science 4:438.

Ahner, J., and M. Schmidt. 2011. Modellierung der Einzelbaummortalität im Hessischen Ried unter besonderer Berücksichtigung von Grundwassserveränderungen. Pages 157-172 in Sektion Ertragskunde DVFFA, editor. Tagungsband der Jahrestagung der Sektion Ertragskunde im DVFFA vom 06.-08.06.2011 in Cottbus, Göttingen.

Allen, C. D., et al. 2010. A global overview of drought and heatinduced tree mortality reveals emerging climate change risks for forests. Forest Ecology and Management 259:660-684.

Anderegg, W. R. L., et al. 2015. Pervasive drought legacies in forest ecosystems and their implications for carbon cycle models. Science 349:528-532.

Berdanier, A. B., and J. S. Clark. 2016. Multiyear droughtinduced morbidity preceding tree death in southeastern US forests. Ecological Applications 26:17-23.

Bigler, C., and H. Bugmann. 2003. Growth-dependent tree mortality models based on tree rings. Canadian Journal of Forest Research 33:210-221.

Bigler, C., and H. Bugmann. 2004. Predicting the time of tree death using dendrochronological data. Ecological Applications 14:902-914.

Bigler, C., J. Gričar, H. Bugmann, and K. Čufar. 2004. Growth patterns as indicators of impending tree death in silver fir. Forest Ecology and Management 199:183-190.

Bircher, N., M. Cailleret, and H. Bugmann. 2015. The agony of choice: different empirical mortality models lead to sharply different future forest dynamics. Ecological Applications 25:1303-1318.

Boeck, A., J. Dieler, P. Biber, H. Pretzsch, and D. P. Ankerst. 2014. Predicting tree mortality for European beech in southern Germany using spatially explicit competition indices. Forest Science 60:613-622.

Bonan, G. B. 2008. Forests and climate change: forcings, feedbacks, and the climate benefits of forests. Science 320: 1444-1449.

Brang, P., H. Bugmann, and C. Heiri. 2011. Waldreservate. 50 Jahre natürliche Waldentwicklung in der Schweiz. Haupt, Birmensdorf, Eidg. Forschungsanstalt WSL; Zürich, ETH Zürich. Bern, Stuttgart, Wien, Austria.

Bravo-Oviedo, A., H. Sterba, M. Del Río, and F. Bravo. 2006. Competition-induced mortality for Mediterranean Pinus pinaster Ait. and P. sylvestris L. Forest Ecology and Management 222:88-98. 
Breiman, L., J. Friedman, C. J. Stone, and R. A. Olshen. 1984. Classification and regression trees. Wadsworth, Belmont, California, USA.

Buchman, R. G., S. P. Pederson, and N. R. Walters. 1983. A tree survival model with application to species of the great-lakes region. Canadian Journal of Forest Research 13:601-608.

Bugmann, H. 1996. A simplified forest model to study species composition along climate gradients. Ecology 77:2055-2074.

Cailleret, M., et al. 2016. Towards a common methodology for developing logistic tree mortality models based on ring-width data. Ecological Applications 26:1827-1841.

Charrier, G., H. Cochard, and T. Améglio. 2013. Evaluation of the impact of frost resistances on potential altitudinal limit of trees. Tree Physiology 33:891-902.

Commarmot, B., H. Bachofen, Y. Bundziak, A. Bürgi, B. Ramp, Y. Shparyk, D. Sukhariuk, R. Viter, and A. Zingg. 2005. Structures of virgin and managed beech forests in Uholka (Ukraine) and Sihlwald (Switzerland): a comparative study. Forest Snow and Landscape Research 79:45-56.

Commarmot, B., U. B. Brändli, F. Hamor, and V. Lavnyy, editors. 2013. Inventory of the largest primeval beech forest in Europe. A Swiss-Ukrainian scientific adventure. Birmensdorf, Swiss Federal Research Institute WSL; L'viv, Ukrainian National Forestry University; Rakhiv, Carpathian Biosphere Reserve.

Dietze, M. C., and P. R. Moorcroft. 2011. Tree mortality in the eastern and central United States: patterns and drivers. Global Change Biology 17:3312-3326.

Dobbertin, M. 2005. Tree growth as indicator of tree vitality and of tree reaction to environmental stress: a review. European Journal of Forest Research 124:319-333.

Dobbertin, M., and P. Brang. 2001. Crown defoliation improves tree mortality models. Forest Ecology and Management 141:271-284.

Dursky, J. 1997. Modellierung der Absterbeprozesse in Reinund Mischbeständen aus Fichte und Buche. Allgemeine Forst- und Jagdzeitung 168:131-134.

Eid, T., and E. Tuhus. 2001. Models for individual tree mortality in Norway. Forest Ecology and Management 154:69-84.

Fawcett, T. 2006. An introduction to ROC analysis. Pattern Recognition Letters 27:861-874.

Fortin, M., and L. Langevin. 2011. Stochastic or deterministic single-tree models: Is there any difference in growth predictions? Annals of Forest Science 69:271-282.

Franklin, J. F., H. H. Shugart, and M. E. Harmon. 1987. Tree death as an ecological process: the causes, consequences and variability of tree mortality. BioScience 37:550-556.

Friend, A. D., et al. 2014. Carbon residence time dominates uncertainty in terrestrial vegetation responses to future climate and atmospheric $\mathrm{CO}_{2}$. Proceedings of the National Academy of Sciences USA 111:3280-3285.

Gauer, J., and E. Aldinger, editors. 2005. Waldökologische Naturräume Deutschlands-Forstliche Wuchsgebiete und Wuchsbezirke - mit Karte 1:10.000. Mitteilungen des Vereins für Forstliche Standortskunde und Forstpflanzenzüchtung Heft Nr. 43.

Gendreau-Berthiaume, B., S. E. Macdonald, and J. J. Stadt. 2016. Extended density-dependent mortality in mature conifer forests: causes and implications for ecosystem management. Ecological Applications 26:1486-1502.

Geßler, A., C. Keitel, J. Kreuzwieser, R. Matyssek, W. Seiler, and H. Rennenberg. 2007. Potential risks for European beech (Fagus sylvatica L.) in a changing climate. Trees-Structure and Function 21:1-11.

Gillner, S., N. Rüger, A. Roloff, and U. Berger. 2013. Low relative growth rates predict future mortality of common beech (Fagus sylvatica L.). Forest Ecology and Management 302: 372-378.
Harcombe, P. A. 1987. Tree life tables. BioScience 37:557-568.

Hasenauer, H. 1994. Ein Einzelbaumwachstumssimulator für ungleichaltrige Fichten-, Kiefern- und Buchen-Fichtenmischbestände. Österreichische Gesellschaft für Waldökosystemforschung und experimentelle Baumforschung, Universität für Bodenkultur, Wien, Austria.

Hastie, T., R. Tibshirani, and J. Friedman. 2001. The elements of statistical learning: data mining, inference, and prediction. Springer, New York, New York, USA.

Hawkes, C. 2000. Woody plant mortality algorithms: description, problems and progress. Ecological Modelling 126: 225-248.

Heiri, C., A. Wolf, L. Rohrer, and H. Bugmann. 2009. Forty years of natural dynamics in Swiss beech forests: structure, composition, and the influence of former management. Ecological Applications 19:1920-1934.

Heiri, C., P. Brang, B. Commarmot, J. F. Matter, and H. Bugmann. 2011. Walddynamik in Schweizer Naturwaldreservaten: Kennzahlen und Trends. Pages 74-89 in P. Brang, C. Heiri, and H. Bugmann, editors. Waldreservate. 50 Jahre natürliche Waldentwicklung in der Schweiz. Haupt, Birmensdorf, Eidg. Forschungsanstalt WSL; Zürich, ETH Zürich. Bern, Stuttgart, Wien, Austria.

Hobi, M. L., B. Commarmot, and H. Bugmann. 2015. Pattern and process in the largest primeval beech forest of Europe (Ukrainian Carpathians). Journal of Vegetation Science 26:323-336.

Holzwarth, F., A. Kahl, J. Bauhus, and C. Wirth. 2013. Many ways to die: partitioning tree mortality dynamics in a nearnatural mixed deciduous forest. Journal of Ecology 101: 220-230.

Hosmer, D. W., and S. Lemeshow. 2000. Assessing the fit of the model. Pages 143-202 in Applied logistic regression. John Wiley \& Sons Inc., New York.

Jung, T. 2009. Beech decline in Central Europe driven by the interaction between Phytophthora infections and climatic extremes. Forest Pathology 39:73-94.

Jutras, S., H. Hokka, V. Alenius, and H. Salminen. 2003. Modeling mortality of individual trees in drained peatland sites in Finland. Silva Fennica 37:235-251.

Keane, R. E., M. Austin, C. Field, A. Huth, M. J. Lexer, D. Peters, A. Solomon, and P. Wyckoff. 2001. Tree mortality in gap models: application to climate change. Climatic Change 51:509-540.

Lakatos, F., and M. Molnár. 2009. Mass mortality of beech (Fagus sylvatica L.) in South-West Hungary. Acta Silvatica et Lignaria Hungarica 5:75-82.

Larocque, G. R., L. Archambault, and C. Delisle. 2011. Development of the gap model ZELIG-CFS to predict the dynamics of North American mixed forest types with complex structures. Ecological Modelling 222:2570-2583.

Lawson, C. R., J. A. Hodgson, R. J. Wilson, and S. A. Richards. 2014. Prevalence, thresholds and the performance of presence-absence models. Methods in Ecology and Evolution 5:54-64.

Lek, S. 2007. Uncertainty in ecological models. Ecological Modelling 207:1-2.

Lorimer, C. G., and L. E. Frelich. 1984. A simulation of equilibrium diameter distributions of sugar maple (Acer saccharum). Bulletin of the Torrey Botanical Club 111:193-199.

Lutz, J. A. 2015. The evolution of long-term data for forestry: large temperate research plots in an era of global change. Northwest Science 89:255-269.

McDowell, N. G., M. G. Ryan, M. J. B. Zeppel, and D. T. Tissue. 2013. Improving our knowledge of drought-induced forest mortality through experiments, observations, and modeling. New Phytologist 200:289-293. 
Metcalf, C. J. E., S. M. McMahon, and J. S. Clark. 2009. Overcoming data sparseness and parametric constraints in modeling of tree mortality: a new nonparametric Bayesian model. Canadian Journal of Forest Research 39:1677-1687.

Meyer, P., and M. Schmidt. 2011. Accumulation of dead wood in abandoned beech (Fagus sylvatica L.) forests in northwestern Germany. Forest Ecology and Management 261:342-352.

Meyer, P., K. Lorenz, A. Mölder, R. Steffens, W. Schmidt, T. Kompa and A. Wevell von Krüger. 2015. Naturwälder in Niedersachsen, Schutz und Forschung - Band 2 (Bergland). Nordwestdeutsche Forstliche Versuchsanstalt, Göttingen; Niedersächsische Landesforsten, Braunschweig.

Meyer, P., A. Wevell von Krüger, R. Steffens, and W. Unkrig. 2006. Naturwälder in Niedersachsen, Schutz und Forschung Band 1 (Tiefland). Nordwestdeutsche Forstliche Versuchsanstalt, Göttingen; Niedersächsische Landesforsten, Braunschweig.

Monserud, R. A. 1976. Simulation of forest tree mortality. Forest Science 22:438-444.

Monserud, R. A., and H. Sterba. 1999. Modeling individual tree mortality for Austrian forest species. Forest Ecology and Management 113:109-123.

Mosteller, F., and J. W. Tukey. 1977. Data analysis and regression: a second course in statistics. Addison-Wesley, Reading, Massachusetts, USA.

Nagel, T. A., M. Svoboda, and M. Kobal. 2014. Disturbance, life history traits, and dynamics in an old-growth forest landscape of southeastern Europe. Ecological Applications 24:663-679.

Neuner, S., et al. 2015. Survival of Norway spruce remains higher in mixed stands under a dryer and warmer climate. Global Change Biology 21:935-946.

Nothdurft, A. 2013. Spatio-temporal prediction of tree mortality based on long-term sample plots, climate change scenarios and parametric frailty modeling. Forest Ecology and Management 291:43-54.

Peterken, G. F. 1996. Natural woodland: ecology and conservation in northern temperate regions. Cambridge University Press, Cambridge, UK.

R Core Team. 2015. R: A Language and environment for statistical computing. R Foundation for Statistical Computing, Vienna, Austria.

Radtke, P. J., N. D. Herring, D. L. Loftis, and C. E. Keyser. 2012. Evaluating forest vegetation simulator predictions for southern Appalachian upland hardwoods with a modified mortality model. Southern Journal of Applied Forestry 36:61-70.

Rasche, L., L. Fahse, A. Zingg, and H. Bugmann. 2012. Enhancing gap model accuracy by modeling dynamic height growth and dynamic maximum tree height. Ecological Modelling 232:133-143.

Reineke, L. H. 1933. Perfecting a stand density index for evenaged forests. Journal of Agricultural Research 46:627-638.

Reyer, C., et al. 2015. Forest resilience and tipping points at different spatio-temporal scales: approaches and challenges. Journal of Ecology 103:5-15.

Scharnweber, T., M. Manthey, C. Criegee, A. Bauwe, C. Schröder, and M. Wilmking. 2011. Drought matters: declining precipitation influences growth of Fagus sylvatica L. and Quercus robur L. in north-eastern Germany. Forest Ecology and Management 262:947-961.
Stahel, W. 2008. Statistische Datenanalyse: eine Einführung für Naturwissenschaftler. 5., überarb. Aufl. edition. Vieweg, Wiesbaden, Germany.

Steinkamp, J., T. Hickler, and D. Gibson. 2015. Is droughtinduced forest dieback globally increasing? Journal of Ecology 103:31-43.

Steyerberg, E. W., A. J. Vickers, N. R. Cook, T. Gerds, M. Gonen, N. Obuchowski, M. J. Pencina, and M. W. Kattan. 2010. Assessing the performance of prediction models: a framework for traditional and novel measures. Epidemiology 21:128-138.

Trotsiuk, V., M. L. Hobi, and B. Commarmot. 2012. Age structure and disturbance dynamics of the relic virgin beech forest Uholka (Ukrainian Carpathians). Forest Ecology and Management 265:181-190.

Wang, W., C. Peng, D. D. Kneeshaw, G. R. Larocque, and Z. Luo. 2012. Drought-induced tree mortality: ecological consequences, causes, and modeling. Environmental Reviews 20:109-121.

Waring, R. H. 1987. Characteristics of trees predisposed to die. BioScience 37:569-574.

Weiskittel, A. R., D. W. Hann, J. A. Kershaw, and J. K. Vanclay. 2011. Mortality. Pages 139-155 in Forest growth and yield modeling. John Wiley \& Sons, Ltd, West Sussex, UK

Wernsdörfer, H., V. Rossi, G. Cornu, S. Oddou-Muratorio, and S. Gourlet-Fleury. 2008. Impact of uncertainty in tree mortality on the predictions of a tropical forest dynamics model. Ecological Modelling 218:290-306.

Woolley, T., D. C. Shaw, L. M. Ganio, and S. Fitzgerald. 2012. A review of logistic regression models used to predict post-fire tree mortality of western North American conifers. International Journal of Wildland Fire 21:1-35.

Wunder, J., B. Reineking, J. F. Matter, C. Bigler, and H. Bugmann. 2007. Predicting tree death for Fagus sylvatica and Abies alba using permanent plot data. Journal of Vegetation Science 18:525-534.

Wunder, J., B. Brzeziecki, H. Zybura, B. Reineking, C. Bigler, and H. Bugmann. 2008. Growth-mortality relationships as indicators of life-history strategies: a comparison of nine tree species in unmanaged European forests. Oikos 117:815-828.

Wyckoff, P. H., and J. S. Clark. 2002. The relationship between growth and mortality for seven co-occurring tree species in the southern Appalachian Mountains. Journal of Ecology 90:604-615.

Yang, Y., and S. Huang. 2013. A generalized mixed logistic model for predicting individual tree survival probability with unequal measurement intervals. Forest Science 59: 177-187.

Yoda, K., T. Kira, H. Ogawa, and K. Hozumi. 1963. Selfthinning in overcrowded pure stands under cultivated and natural conditions (intraspecific competition among higher plants XI). Journal of Biology, Osaka City University 14:107-129.

Zimmermann, J., M. Hauck, C. Dulamsuren, and C. Leuschner. 2015. Climate warming-related growth decline affects Fagus sylvatica, but not other broad-leaved tree species in central European mixed forests. Ecosystems 18:560-572.

\section{SUPPORTING INFORMATION}

Additional Supporting Information may be found online at: http://onlinelibrary.wiley.com/doi/10.1002/eap.1388/suppinfo

\section{Data Avallability}

Data associated with this paper have been deposited in Dryad: http://dx.doi.org/10.5061/dryad.h4s6t 